\title{
Comparison of meta-heuristic algorithms for fuzzy modelling of COVID-19 illness' severity classification
}

\author{
Nur Azieta Mohamad Aseri' ${ }^{1}$, Mohd Arfian Ismail ${ }^{1}$, Abdul Sahli Fakharudin ${ }^{1,2}$, Ashraf Osman \\ Ibrahim $^{2,3}$, Shahreen Kasim ${ }^{4}$, Noor Hidayah Zakaria ${ }^{5}$, Tole Sutikno ${ }^{6}$ \\ ${ }^{1}$ Faculty of Computing, Universiti Malaysia Pahang, Pahang, Malaysia \\ ${ }^{2}$ Faculty of Computer Science and Information Technology, Alzaiem Alazhari University, Khartoum North, Sudan \\ ${ }^{3}$ Arab Open University, Khartoum, Sudan \\ ${ }^{4}$ Faculty of Computing Science and Information Technology, Universiti Tun Hussein Onn, Johor, Malaysia \\ ${ }^{5}$ School of Computing, Faculty of Engineering, Universiti Teknologi Malaysia, Johor, Malaysia \\ ${ }^{6}$ Department of Electrical Engineering, Universitas Ahmad Dahlan, Yogyakarta, Indonesia
}

\begin{abstract}
Article Info
\section{Article history:}

Received Sep 6, 2021

Revised Sep 22, 2021

Accepted Oct 28, 2021

\section{Keywords:}

COVID-19

Differential evolution

Fuzzy logic

Genetic algorithm

Meta-heuristic

Particle swarm optimization

TLBO Algorithm

ABSTRACT

The world health organization (WHO) proclaimed the COVID-19, commonly known as the coronavirus disease 2019, was a pandemic in March 2020. When people are in close proximity to one another, the virus spreads mostly through the air. It causes some symptoms in the affected person. COVID-19 symptoms are quite variable, ranging from none to severe sickness. As a result, the fuzzy method is seen favourably as a tool for determining the severity of a person's COVID-19 sickness. However, when applied to a large situation, manually generating a fuzzy parameter is challenging. This could be because of the identification of a large number of fuzzy parameters. A mechanism, such as an automatic procedure, is consequently required to identify the right fuzzy parameters. The metaheuristic algorithm is regarded as a viable strategy. Five meta-heuristic algorithms were analyzed and utilized in this article to classify the severity of COVID-19 sickness data. The performance of the five meta-heuristic algorithms was evaluated using the COVID-19 symptoms dataset. The COVID-19 symptom dataset was created in accordance with WHO and the Indian ministry of health and family welfare criteria. The findings provide the average classification accuracy for each approach.
\end{abstract}

This is an open access article under the CC BY-SA license.

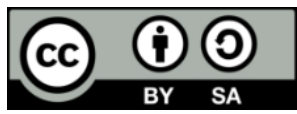

\section{Corresponding Author:}

Mohd Arfian Ismail

Faculty of Computing, Universiti Malaysia Pahang

26600 Pekan, Pahang, Malaysia

Email: arfian@ump.edu.my

\section{INTRODUCTION}

A newly found coronavirus, severe acute respiratory syndrome coronavirus 2 (SARS-CoV-2), has triggered a global pandemic of respiratory sickness dubbed coronavirus disease 2019 (COVID-19) [1]-[24]. COVID-19 appears to be more contagious than influenza and results in more serious diseases in certain people [5], [11], [15]. COVID-19 has a variable effect on individuals. COVID-19 infection has been associated with a wide variety of symptoms, ranging from mild to severe illness. Symptoms often manifest 214 days following viral contact. Fever, fatigue, a dry cough, difficulty breathing, sore throat, nasal congestion, runny nose, and diarrhoea are just a few of the pre-defined typical symptoms. These symptoms are based on world health organization (WHO) regulations [3], [12], [13], [19], [20], [25]. The severity of the sickness assists the medical team in isolating patients and providing appropriate health care. 
It was found that using the fuzzy system is a suitable approach in identifying to identify the severity of the COVID-19 illness as it implements fuzzy logic and approximate reasoning [26], [27]. In addition, the fuzzy system also uses expert knowledge to ensure the system performs better. Fuzzy parameters are required to ensure the system able to work, and this process is called fuzzy modelling [26], [28]-[36]. Regrettably, when used to sophisticated problems such as engineering or medicine, the fuzzy systems architecture becomes complicated [26], [37]-[44]. This could occur as a result of the detection of numerous fuzzy parameters. A method for determining the suitable fuzzy parameters is required to address this issue [26], [33], [36], [45]-[61]. As a result, an automated procedure for identifying fuzzy parameters was developed [33], [36], [46], [62]-[66].

Fuzzy modelling is possible to be automated using metaheuristic algorithms. Metaheuristic algorithms are a type of computational intelligence paradigm that is particularly well-suited for solving complex optimization problems [29], [67]-[75]. Metaheuristic algorithms is potential to construct an automated method for determining the severity of a COVID-19 infection infected person based their symptoms [76]. Five metaheuristic algorithms were employed in this work to assess the severity of people's COVID-19 illness: differential evolution (DE), teaching-learning-based optimization (TLBO), particle swarm optimization (PSO), genetic algorithm (GA), and bat algorithm (BA). The next section describes these methods and illustrates them using their existing implementations.

\section{META-HEURISTIC ALGORITHMS}

\subsection{Differential evolution}

Differential evolution (DE) is a form of evolutionary algorithm invented by Storn and Price [77]. $\mathrm{DE}$ is a fast evolutionary algorithm (EA) that was developed for the purpose of solving optimization problems with real-valued parameters [73], [78]-[96]. DE enables the resolution of optimization problems by maintaining a population of candidate solutions. It generates new candidate solutions by merging existing solutions in the current generation to solve the optimization problem and retaining the candidate solution with the highest quality in the subsequent generation. DE is a three-step process that includes mutation crossover and selection [86], [97]-[100]. The flowchart in Figure 1 depicts the DE process.

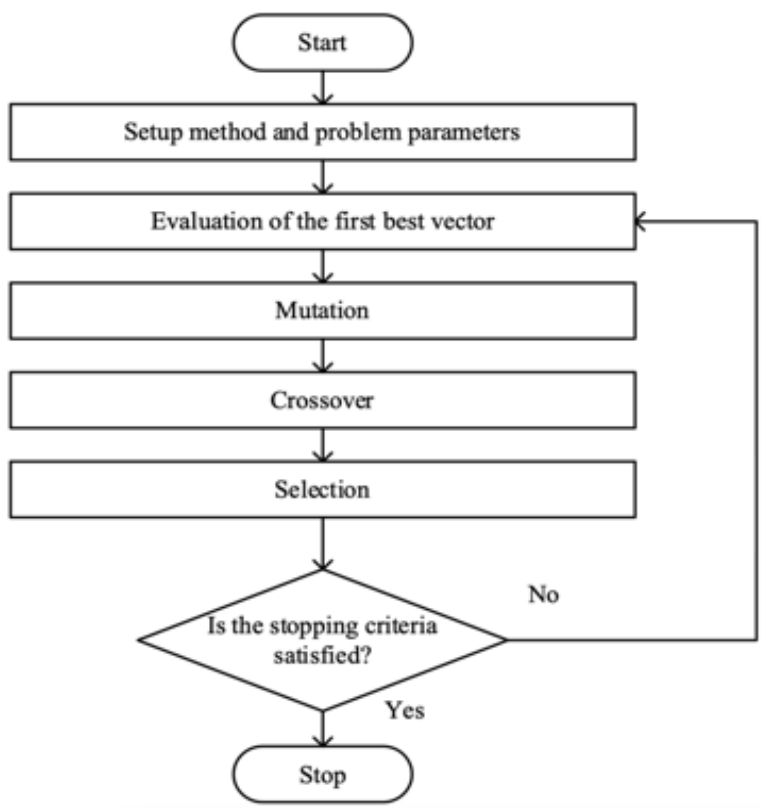

Figure 1. Flowchart of DE

\subsection{Genetic algorithm}

Genetic algorithm (GA) was introduced by John Holland in 1975 [101] mimics the natural concepts, which are genetic to represent the solution and selection, crossover, mutation to perform its operation. At each phase, GAs employ three distinct sorts of rules to generate the next generation from the present population: selection, crossover, and mutation [93], [95], [102]-[113]. Selection rules determine which individuals, referred to as parents, contribute to the population in the following generation. Crossover rules 
create the subsequent generation by combining the offspring of two parents. Individual parents are subjected to random mutations in order to produce children. The process of GA is depicted in flowchart form in Figure 2.

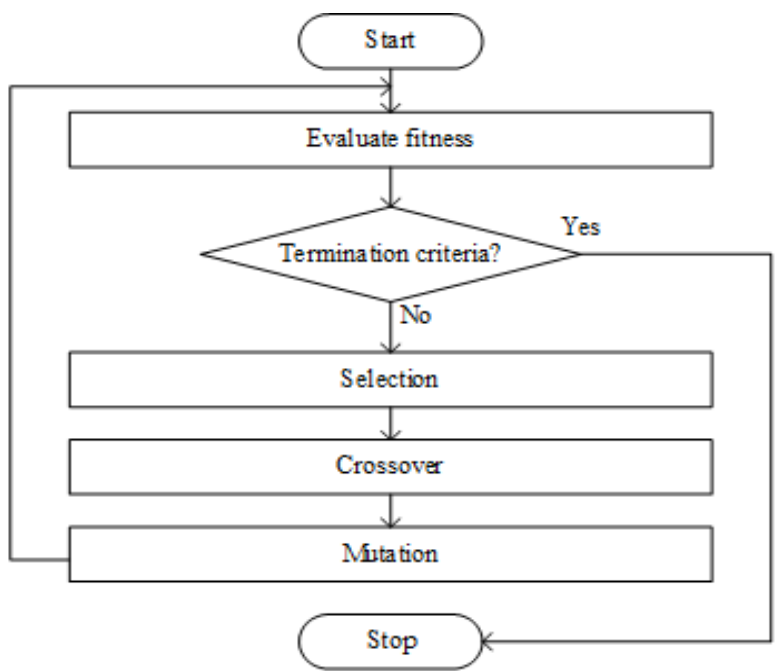

Figure 2. Flowchart of GA

\subsection{Particle swarm optimization}

Particle swarm optimization (PSO) is a form of swarm intelligence and swarm search that evolved from artificial life and evolutionary computation [114]-[124]. It is modelled after the social behaviour of flocking birds or schooling fish [124]. Since its inception in 1995, PSO has been successfully employed as a solution to a variety of function optimization problems or problems that able to be turned into function optimization problems [116]. Due to its lower memory needs and superior performance in offering solutions that are closer to the optimal for a variety of benchmarks and technical challenges such as computer vision [72], [93], [114], [120], [125]-[158]. PSO has become one of the most popular methods for tackling optimization problems [116][159]-[161]. The operation of PSO is depicted in flowchart form in Figure 3.

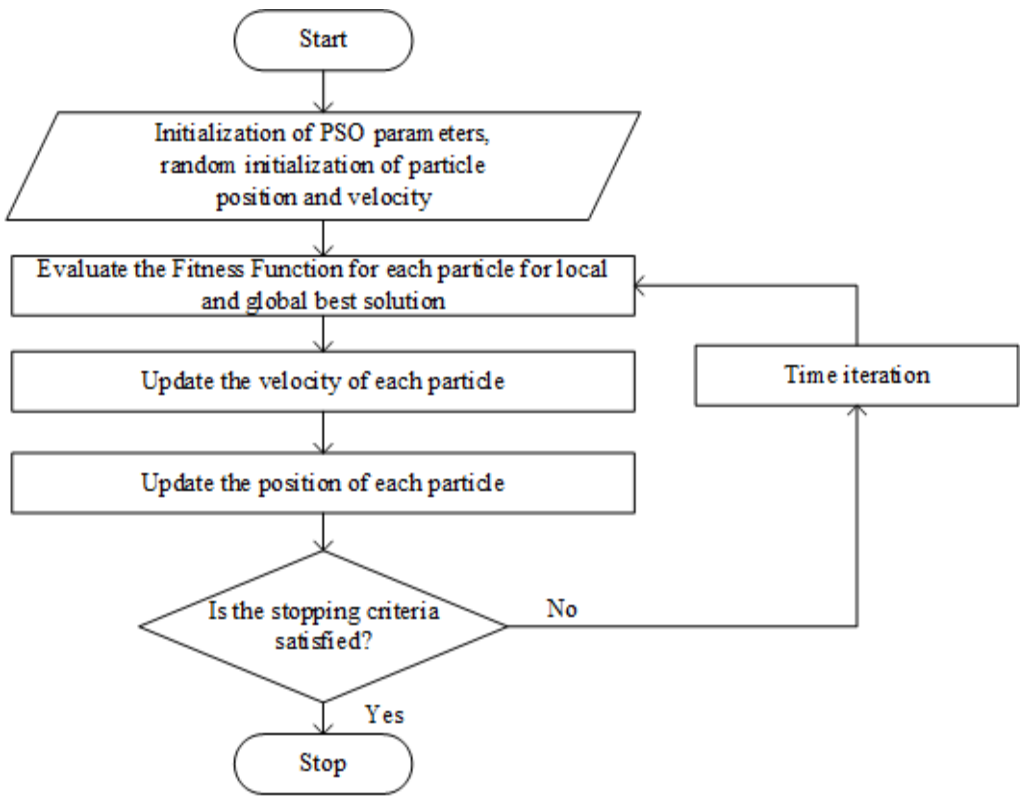

Figure 3. Flowchart of PSO algorithm 


\subsection{Teaching-learning-based optimization}

The teacher-learning-based optimization (TLBO) algorithm is a novel form of metaheuristic algorithm motivated by the teaching-learning process. The TLBO method is a population-based optimization technique in which a group or class of students is considered a population. Each student is an embodiment of a potential solution to the problem. The numerous courses offered in class are interpreted as diverse design variables for the optimization problem, and students performance is interpreted as the fitness value of probable solutions to the optimization problem. The TLBO algorithm is separated into two phases: teacher and student [79], [162]-[170].

The teacher phase is the stage during which pupils learn directly from the teacher. According to the teaching-learning concept, the teacher is defined as the most experienced, knowledgeable, and highly educated member of society. The teacher makes an effort to increase pupils knowledge and to assist students in achieving high grades. Pupils, on the other hand, acquire knowledge and earn grades based on the quality of their teachers instruction and the quality of their classmates. Students acquire information throughout the student phase through mutual engagement. To improve knowledge, a student interacts randomly with other students in the class. If another student in the class has more knowledge than the former, the latter will teach the former something new. Thus, if the latter student is superior to the former, the former student is relegated to the latter. Otherwise, the former student will be separated from the latter. TLBO operates and processes in the manner depicted in Figure 4.

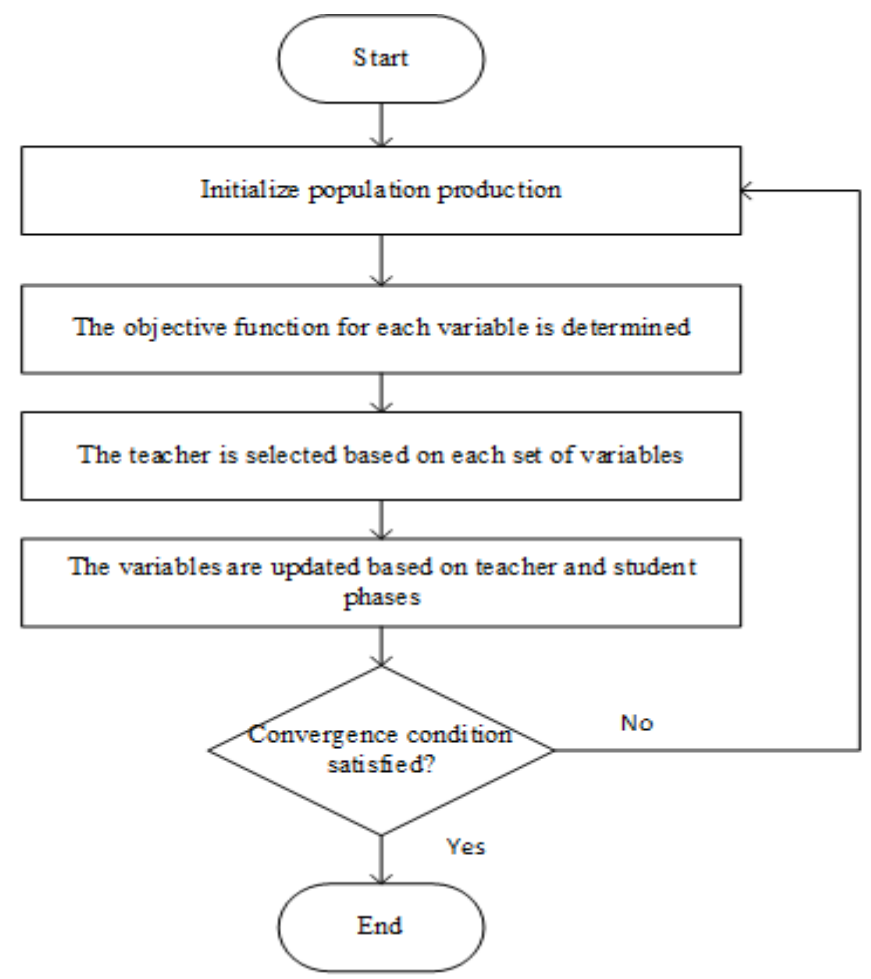

Figure 4. Flowchart of TLBO algorithm

\subsection{Bat algorithm}

The bat algorithm (BA) was introduced by Yang [171] in 2010 as a way for searching for global optimal solutions. BA has gained increased attention due to its simplicity, a small number of parameters, high robustness, and ease of implementation [144], [172]-[177]. The BA is designed to replicate bats echolocation activity. Bats generate a very loud sound pulse and listen for echoes in their environment. This signal varies according to the species of bat [178]. BA is founded on two tenets: i) all bats utilize echolocation and fly randomly in search of prey; and ii) all bats use echolocation. They distinguish between victim or food and impediment or background barriers; iii) bats utilize echolocation to determine distance. Bats able to automatically alter the wavelength of their outgoing pulses in response to their target. Figure 5 illustrates the steps required in $\mathrm{BA}$. 


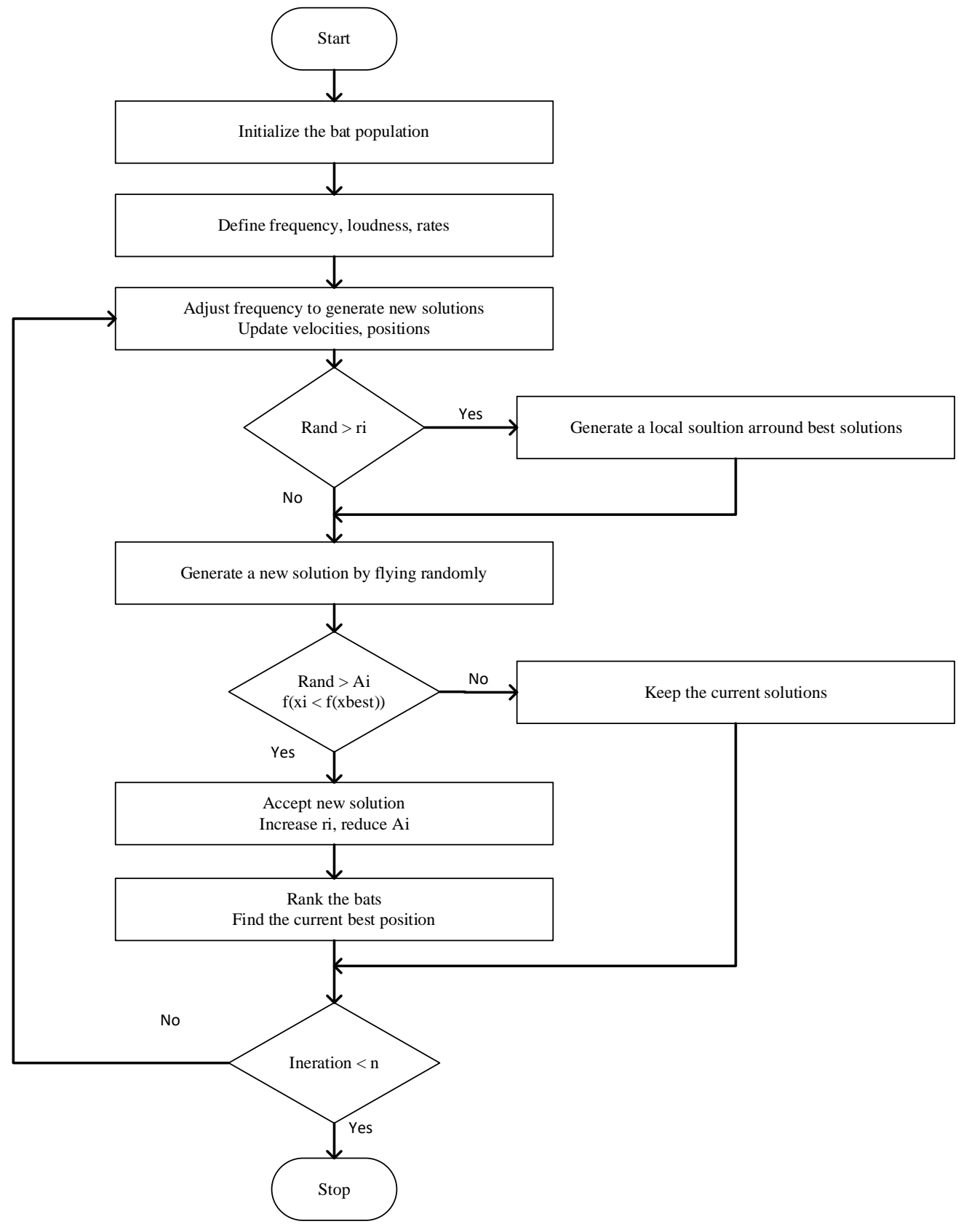

Figure 5. Flowchart of BAT algorithm

\section{FUZZY META-HEURISTIC ALGORITHMS}

This section discusses how meta-heuristic algorithms [29], [67]-[70], [73]-[75], [82], [90], [95], [109], [119], [160], [163], [176], [179]-[188] are included in the fuzzy modelling process. The implementation of fuzzy meta-heuristic algorithms is depicted in Figure 6. The initialization of the first population is the first process. The fuzzy parameters, including the fuzzy rules and fuzzy membership function, were produced randomly and represented by candidate solutions during this process. Figure 7 illustrates the representation of fuzzy rules and the fuzzy membership functions. Following that, the fuzzy rules and fuzzy membership functions are evaluated [189]. The fuzzy system classified data using fuzzy rules and the fuzzy membership functions. At this stage, proposed solutions were reviewed to see if they satisfied the termination requirement or not. If the termination requirement is met, the process terminates, and the optimal solution is found; and the process will continue when the termination condition is not achieved. The reproduction procedure seeks to increase the candidate solutions quality. The replication procedure is dependent on the meta-heuristic algorithm utilized in the fuzzy modelling process [29], [88], [180]. 


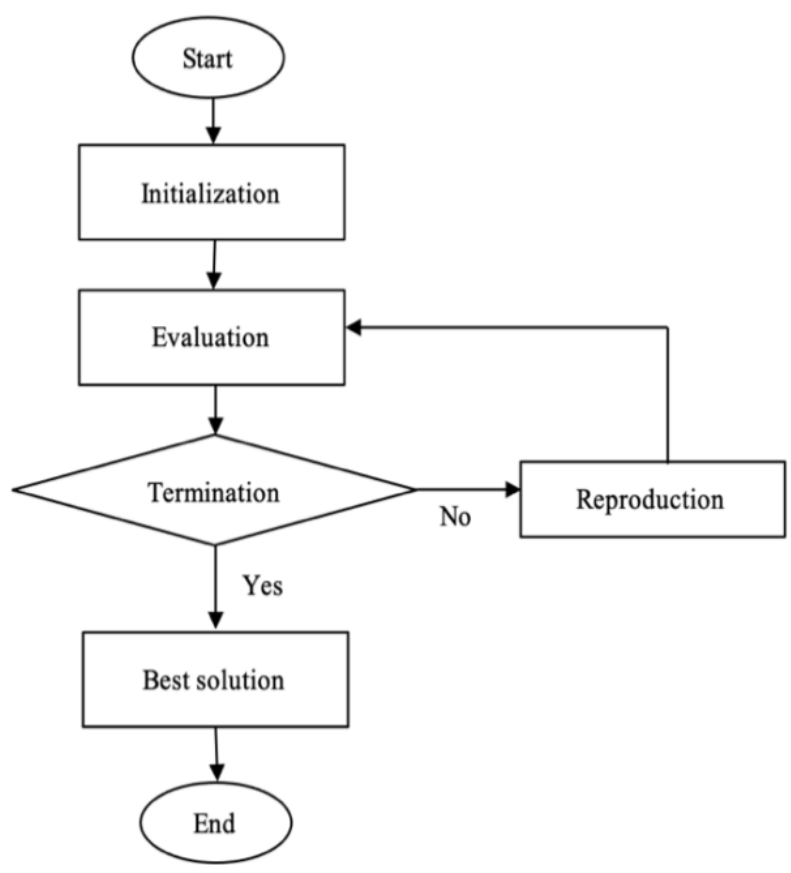

Figure 6. Flowchart of fuzzy meta-heuristic algorithm

Fuzzy rule

IF $\left(V_{1}^{\prime}\right.$ IS $\left.A_{1}^{\prime}\right)$ AND $\left(V_{2}^{\prime}\right.$ IS $\left.A_{2}^{\prime}\right)$ AND ...... ( $V_{n}^{\prime}$ IS $\left.A_{n}^{\prime}\right)$ THEN (CL IS $\left.C\right)$

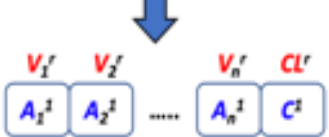

$V$ and $C=$ linguistic variable (attribute of

$$
\text { data) }
$$

A and $\mathrm{C}=$ linguistic value (value of data)

$n=$ no. of attribute

$r=$ no of rule

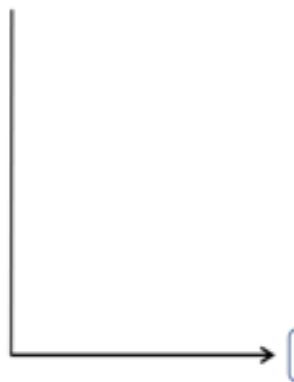

2

Fuzzy membership function

Degree of membership function

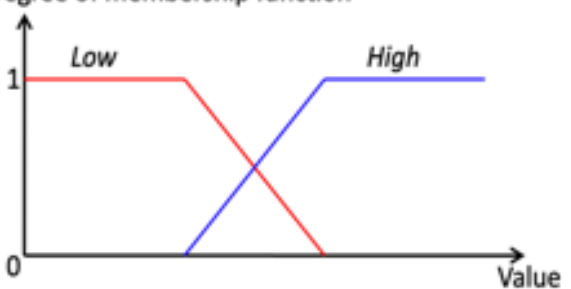

\begin{tabular}{|l|l|l|l|l|}
\hline 4 & 1 & 3 & 8 & 1 \\
\hline
\end{tabular}

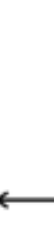

Candidate solution

Figure 7 . The representation of fuzzy rules and fuzzy membership function

\section{EXPERIMENTAL DATA}

In evaluating the performance of metaheuristic algorithms, the COVID-19 symptoms checker dataset was utilized. This dataset is available for download on the Kaggle website at https://www.kaggle.com/iamhungundji/covid19-symptoms-checker. This dataset contains information on COVID-19 classification (whether or not a person has the disease) based on a set of pre-defined standard symptoms. These symptoms are based on WHO and the Indian Ministry of Health and Family Welfare recommendations. The dataset contains significant variables that is utilized to determine whether or not someone has coronavirus illness. There are 316801 instances in the dataset. 


\section{RESULTS AND DISCUSSION}

Following the collection of data, the performance of each machine-learning technique was examined. The various experiments results were presented and contrasted. The results revealed disparate values for various variables, including the number of correctly identified occurrences and the time required to execute the experiment. Table 1 gives the experiment's results. From the table, the fuzzy DE and fuzzy PSO algorithms performed well, with an average accuracy of 74.9 percent, followed by the fuzzy GA at 25.6 percent. Fuzzy TLBO and fuzzy BA had the lowest average accuracies at 25.1 percent each.

Table 1. The result of the meta-heuristic algorithm for fuzzy modelling in the classification of COVID-19

\begin{tabular}{cc}
\hline Method & Average accuracy $(\%)$ \\
\hline Fuzzy DE & 74.9 \\
Fuzzy GA & 25.6 \\
Fuzzy PSO & 74.9 \\
Fuzzy TLBO & 25.1 \\
Fuzzy BA & 25.1 \\
\hline
\end{tabular}

Along with average accuracy, computational time was considered. Table 2 summarises the time required (in minutes) for each machine-learning approach to handle both datasets. According to the table, fuzzy DE outperformed the other approaches for both datasets. This could be due to the speed with which fuzzy DE performed the classification process, as it worked with the maximum margin, allowing for extremely low classification error [190]. It is robust and quick in classifying objects [191], [192]. Meanwhile, fuzzy TLBO required the most time to classify all datasets. This could be because the fuzzy TLBO's slow training procedure utilized a large amount of computer memory, making it time demanding [193]-[195]. The comparison of time expresses in Table 2.

Table 2. The comparison of time

\begin{tabular}{cc}
\hline Method & Computational time $(\mathrm{sec})$ \\
\hline Fuzzy DE & 5.9771 \\
Fuzzy GA & 11.4683 \\
Fuzzy PSO & 6.5285 \\
Fuzzy TLBO & 146.7146 \\
Fuzzy BA & 14.5643 \\
\hline
\end{tabular}

\section{CONCLUSION}

Machine learning is one of the methods that is suitable to be applied for classifying the severity of peoples COVID-19 illnesses. Five machine-learning algorithms were evaluated in this study: fuzzy DE, fuzzy GA, fuzzy PSO, fuzzy TLBO, and fuzzy BA. The benchmark dataset was created in accordance with WHO requirements. The data set included pre-defined standard symptoms such as fever, fatigue, dry coughing, trouble breathing, sore throat, nasal congestion, runny nose, and diarrhoea. Numerous experiments were conducted to show the ability of the methods. The performance criteria included the precision with which the data were classified correctly and the time required to conduct the experiment. As a result of the data, it is clear that fuzzy DE performs admirably in terms of average accuracy and classification time. As a result, the fuzzy DE fared the best in classifying the COVID-19 Symptoms Checker dataset.

\section{ACKNOWLEDGEMENTS}

The authors thank to Universiti Malaysia Pahang, Universiti Tun Hussein Onn, Universiti Teknologi Malaysia and Universitas Ahmad Dahlan for supporting this collaborative research in the present work. This work was supported by the Postgraduate Research Scheme (PGRS) vot No PGRS200396 from Universiti Malaysia Pahang and Universiti Teknologi Malaysia under Grant vot No. PY/2020/04173.

\section{REFERENCES}

[1] W. H. Organization, "Naming the coronavirus disease (COVID-19) and the virus that causes it," 2020. https://www.who.int/emergencies/diseases/novel-coronavirus-2019/technical-guidance/naming-the-coronavirus-disease-(covid2019)-and-the-virus-that-causes-it.

[2] S. Krishnan, P. Magalingam, and R. Ibrahim, "Hybrid deep learning model using recurrent neural network and gated recurrent unit for heart disease prediction," Int. J. Electr. Comput. Eng., vol. 11, no. 6, pp. 5467-5476, 2021, doi: 
10.11591/ijece.v11i6.pp5467-5476.

[3] N. N. Sari, M. N. Gani, R. A. Maharani Yusuf, and R. Firmando, "Telemedicine for silent hypoxia: Improving the reliability and accuracy of Max30100-based system," Indones. J. Electr. Eng. Comput. Sci., vol. 22, no. 3, pp. 1419-1426, 2021, doi: 10.11591/ijeecs.v22.i3.pp1419-1426.

[4] R. Alotaibi and A. Alghamdi, "Studying faculty members' readiness to use Shaqra University e-learning platform," Indones. J. Electr. Eng. Comput. Sci., vol. 22, no. 3, pp. 1556-1564, 2021, doi: 10.11591/ijeecs.v22.i3.pp1556-1564.

[5] N. A. Hidayat, P. Megantoro, A. Yurianta, A. Sofiah, S. A. Aldhama, and Y. A. Effendi, "The application of instrumentation system on a contactless robotic triage assistant to detect early transmission on a COVID-19 suspect," Indones. J. Electr. Eng. Comput. Sci., vol. 22, no. 3, pp. 1334-1344, 2021, doi: 10.11591/ijeecs.v22.i3.pp1334-1344.

[6] E. A. Mahareek, A. S. Desuky, and H. A. El-Zhni, "Simulated annealing for svm parameters optimization in student's performance prediction," Bull. Electr. Eng. Informatics, vol. 10, no. 3, pp. 1211-1219, 2021, doi: 10.11591/eei.v10i3.2855.

[7] T. Wahyuningrum, C. Kartiko, A. C. Wardhana, and T. G. Soares, "Revised web impact factor analysis of timor leste university website during covid-19 pandemic," Bull. Electr. Eng. Informatics, vol. 10, no. 3, pp. 1678-1686, 2021, doi: 10.11591/eei.v10i3.3034.

[8] N. Hayatin, K. M. Ghufron, and G. W. Wicaksono, "Summarization of COVID-19 news documents deep learning-based using transformer architecture," Telkomnika (Telecommunication Comput. Electron. Control., vol. 19, no. 3, pp. 754-761, 2021, doi: 10.12928/TELKOMNIKA.v19i3.18356.

[9] S. Kim and K. You, "Data analysis of financial burden index through KBO league FA pitcher's performance and contract amount size," Int. J. Electr. Comput. Eng., vol. 11, no. 3, pp. 2525-2562, 2021, doi: 10.11591/ijece.v11i3.pp2555-2562.

[10] S. K. Addagarla and A. Amalanathan, "e-SimNet: A visual similar product recommender system for E-commerce," Indones. J. Electr. Eng. Comput. Sci., vol. 22, no. 1, pp. 563-570, 2021, doi: 10.11591/ijeecs.v22.i1.pp563-570.

[11] "Recently employed engineering techniques to reduce the spread of COVID-19 (Corona Virus disease 2019): A review study," Indones. J. Electr. Eng. Comput. Sci., vol. 22, no. 1, pp. 277-286, 2021, doi: 10.11591/ijeecs.v22.11.pp277-286.

[12] M. W. Hasan, "Covid-19 fever symptom detection based on IoT cloud," Int. J. Electr. Comput. Eng., vol. 11, no. 2, pp. 18231829, 2021, doi: 10.11591/ijece.v11i2.pp1823-1829.

[13] M. Al-Smadi, M. Hammad, Q. B. Baker, S. K. Tawalbeh, and S. A. Al-Zboon, "Transfer deep learning approach for detecting coronavirus disease in X-ray images," Int. J. Electr. Comput. Eng., vol. 11, no. 6, pp. 4999-5008, 2021, doi: 10.11591/ijece.v11i6.pp4999-5008.

[14] J. Hurtado and F. Reales, "A machine learning approach for the recognition of melanoma skin cancer on macroscopic images," Telkomnika (Telecommunication Comput. Electron. Control., vol. 19, no. 4, pp. 1357-1368, 2021, doi: 10.12928/TELKOMNIKA.v19i4.20292.

[15] P. Mookdarsanit and L. Mookdarsanit, "The covid-19 fake news detection in thai social texts," Bull. Electr. Eng. Informatics, vol. 10, no. 2, pp. 988-998, 2021, doi: 10.11591/eei.v10i2.2745.

[16] L. Rafea, A. Ahmed, and W. D. Abdullah, "Classification of a COVID-19 dataset by using labels created from clustering algorithms,” Indones. J. Electr. Eng. Comput. Sci., vol. 21, no. 1, pp. 164-173, 2021, doi: 10.11591/ijeecs.v21.i1.pp164-173.

[17] D. C. Tran, "An open toolbox for generating map of actively confirmed sars-cov-2 or covid-19 cases in vietnam," Bull. Electr. Eng. Informatics, vol. 9, no. 6, pp. 2396-2403, 2020, doi: 10.11591/eei.v9i6.2621.

[18] N. H. Hamada and F. F. Kharbat, "P-norms of histogram of oriented gradients (p-HOG) for X-ray images," Int. J. Electr. Comput. Eng., vol. 11, no. 5, pp. 4423-4430, 2021, doi: 10.11591/ijece.v11i5.pp4423-4430.

[19] D. Sanin-Villa, O. D. Monsalve-Cifuentes, and J. S. Del Rio, "Early fever detection on COVID-19 infection using thermoelectric module generators," Int. J. Electr. Comput. Eng., vol. 11, no. 5, pp. 3828-3837, 2021, doi: 10.11591/ijece.v11i5.pp3828-3837.

[20] N. Alrefai and O. Ibrahim, "Deep learning for COVID-19 diagnosis based on chest X-ray images," Int. J. Electr. Comput. Eng., vol. 11, no. 5, pp. 4531-4541, 2021, doi: 10.11591/ijece.v11i5.pp4531-4541.

[21] A. M. Saleh, H. Y. Abuaddous, O. Enaizan, and F. Ghabban, "User experience assessment of a COVID-19 tracking mobile application (AMAN) in Jordan," Indones. J. Electr. Eng. Comput. Sci., vol. 23, no. 2, pp. 1120-1127, 2021, doi: 10.11591/ijeecs.v23.i2.pp1120-1127.

[22] A. Y. Gheni, H. A. Yousif, and Y. Y. Jusoh, "A critical success factors for software project manager in gvts within covid-19 pandemic,” Bull. Electr. Eng. Informatics, vol. 10, no. 4, pp. 2293-2301, 2021, doi: 10.11591/eei.v10i4.3120.

[23] M. M. Khubrani and S. Alam, "A detailed review of blockchain-based applications for protection against pandemic like COVID19," Telkomnika (Telecommunication Comput. Electron. Control., vol. 19, no. 4, pp. 1185-1196, 2021, doi: 10.12928/TELKOMNIKA.v19i4.18465.

[24] M. M. Singh, R. Frank, and W. M. N. Wan Zainon, "Cyber-criminology defense in pervasive environment: A study of cybercrimes in Malaysia," Bull. Electr. Eng. Informatics, vol. 10, no. 3, pp. 1658-1668, 2021, doi: 10.11591/eei.v10i3.3028.

[25] W. H. Organization, "Coronavirus Disease," 2021. https://www.who.int/news-room/q-a-detail/coronavirus-disease-covid-19.

[26] N. S. Nordin, M. A. Ismail, V. Mezhuyev, S. Kasim, M. S. Mohamad, and A. O. Ibrahim, "Fuzzy Modelling using Firefly Algorithm for Phishing Detection," Adv. Sci. Technol. Eng. Syst., vol. 4, no. 6, pp. 291-296, 2019, doi: 10.25046/aj040637.

[27] K. Mahmoud et al., "Prediction of the effects of environmental factors towards COVID-19 outbreak using AI-based models," IAES Int. J. Artif. Intell., vol. 10, no. 1, pp. 35-42, 2021, doi: 10.11591/ijai.v10.i1.pp35-42.

[28] C.-Y. Fan, P.-C. Chang, J.-J. Lin, and J. C. Hsieh, "A hybrid model combining case-based reasoning and fuzzy decision tree for medical data classification," Appl. Soft Comput., vol. 11, no. 1, pp. 632-644, Jan. 2011, doi: 10.1016/j.asoc.2009.12.023.

[29] N. S. Nordin et al., "A comparative analysis of metaheuristic algorithms in fuzzy modelling for phishing attack detection," Indones. J. Electr. Eng. Comput. Sci., vol. 23, no. 2, pp. 1146-1158, 2021, doi: 10.11591/ijeecs.v23.i2.pp1146-1158.

[30] A. Karimi and T. J. Gandomani, "Software development effort estimation modeling using a combination of fuzzy-neural network and differential evolution algorithm," Int. J. Electr. Comput. Eng., vol. 11, no. 1, pp. 707-715, 2021, doi: 10.11591/ijece.v11i1.pp707-715.

[31] M. Z. Ismail, M. H. N. Talib, Z. Ibrahim, J. Mat Lazi, and Z. Rasin, "Experimental simplified rule of self tuning fuzzy logicmodel reference adaptive speed controller for induction motor drive," Indones. J. Electr. Eng. Comput. Sci., vol. 20, no. 3, pp. 1653-1664, 2020, doi: 10.11591/ijeecs.v20.i3.pp1653-1664.

[32] N. N. C. Razali, N. A. Ghani, S. I. Hisham, S. Kasim, N. S. Widodo, and T. Sutikno, "Rainfall-runoff modelling using adaptive neuro-fuzzy inference system," Indones. J. Electr. Eng. Comput. Sci., vol. 17, no. 2, pp. 1117-1126, 2020, doi: 10.11591/IJEECS.V17.I2.PP1117-1126.

[33] L. B. Khuzyatova and L. A. Galiullin, "Optimization of parameters of neuro-fuzzy model," Indones. J. Electr. Eng. Comput. Sci., vol. 19, no. 1, pp. 229-232, 2020, doi: 10.11591/ijeecs.v19.i1.pp229-232.

[34] E. H. Karam, N. A. Al-Awad, and N. S. Abdul-Jaleel, "Design nonlinear model reference with fuzzy controller for nonlinear SISO second order systems," Int. J. Electr. Comput. Eng., vol. 9, no. 4, pp. 2491-2502, 2019, doi: 10.11591/ijece.v9i4.pp2491- 
2402.

[35] Y. S. Triana and A. Retnowardhani, "Enhance interval width of crime forecasting with ARIMA model-fuzzy alpha cut," Telkomnika (Telecommunication Comput. Electron. Control., vol. 17, no. 3, pp. 1193-1201, 2019, doi: 10.12928/TELKOMNIKA.v17i3.12233.

[36] L. B. Khuzyatova and L. A. Galiullin, “Optimization of parameters of neuro-fuzzy model,” Indones. J. Electr. Eng. Comput. Sci., vol. 17, no. 3, pp. 1206-1209, 2019, doi: 10.11591/ijeecs.v17.i3.pp1206-1209.

[37] N. Azieta, M. Aseri, N. A. M. Aseri, M. A. Ismail, A. S. Fakharudin, and A. O. Ibrahim, "Review of The Meta-Heuristic Algorithms for Fuzzy Modeling in The Classification Problem," Int. J., vol. 9, no. 1.4, pp. 387-400, 2020, doi: $10.30534 /$ ijatcse/2020/5691.42020.

[38] I. Alexander, C. Daniel, A. Paúl, and A.-A. Diego, "Performance analysis of optimized controllers with bio-inspired algorithms," Bull. Electr. Eng. Informatics, vol. 9, no. 6, pp. 2507-2517, 2020, doi: 10.11591/eei.v9i6.2619.

[39] J. T. Santoso, M. C. Wibowo, B. Raharjo, and M. Mufadhol, "Gammu and kalkun for information services and sales based on information technology," Int. J. Electr. Comput. Eng., vol. 10, no. 2, pp. 2110-2116, 2020, doi: 10.11591/ijece.v10i2.pp21102116.

[40] K. A. R. Vargas, O. J. S. Parra, and M. J. Espitia Rico, "Temperature monitoring and forecast system in remote areas with 4.0G LTE mobile technologies," Telkomnika (Telecommunication Comput. Electron. Control., vol. 16, no. 5, pp. 1988-2004, 2018, doi: 10.12928/TELKOMNIKA.v16i5.10246.

[41] A. M. Rezaiee and A. Karimi, "A new dynamic intelligent model to determine reliability and trust of online banking by using fuzzy C-mean,” Indones. J. Electr. Eng. Comput. Sci., vol. 4, no. 3, pp. 605-610, 2016, doi: 10.11591/ijeecs.v4.i3.pp605-610.

[42] B. D. Vighneshwari and R. Neela, "Insight on effectiveness of frequently exercised PQ classification techniques," Int. J. Electr. Comput. Eng., vol. 6, no. 5, pp. 2437-2446, 2016, doi: 10.11591/ijece.v6i5.10744.

[43] M. Outanoute, A. Lachhab, A. Ed-Dahhak, M. Guerbaoui, A. Selmani, and B. Bouchikhi, "Synthesis of an optimal dynamic regulator based on linear quadratic Gaussian (LQG) for the control of the relative humidity under experimental greenhouse," Int. J. Electr. Comput. Eng., vol. 6, no. 5, pp. 2262-2273, 2016, doi: 10.11591/ijece.v6i5.10470.

[44] T. Siraj Ahmed, S. Sao, and K. S. R. Anjaneyulu, "Microcontroller based stator resistance determination of induction motor on temperature variations," Int. J. Power Electron. Drive Syst., vol. 4, no. 3, pp. 356-362, 2014, [Online]. Available: https://www.scopus.com/inward/record.uri?eid=2-s2.0-

84901753705\&partnerID=40\&md5=3aed50b0095ad7f71666d07524d8a05a

[45] K. M. Arun Prasad and U. Nair, "Intelligent fuzzy sliding mode controller based on FPGA for the speed control of a BLDC motor," Int. J. Power Electron. Drive Syst., vol. 11, no. 1, pp. 477-486, 2020, doi: 10.11591/ijpeds.v11.i1.pp477-486.

[46] T. Dewi, S. Nurmaini, P. Risma, Y. Oktarina, and M. Roriz, "Inverse kinematic analysis of 4 DOF pick and place arm robot manipulator using fuzzy logic controller," Int. J. Electr. Comput. Eng., vol. 10, no. 2, pp. 1376-1386, 2020, doi: 10.11591/ijece.v10i2.pp1376-1386.

[47] M. Irwanto, H. Alam, M. Masri, B. Ismail, W. Z. Leow, and Y. M. Irwan, "Solar energy density estimation using ANFIS based on daily maximum and minimum temperature," Int. J. Power Electron. Drive Syst., vol. 10, no. 4, pp. 2206-2213, 2019, doi: 10.11591/ijpeds.v10.i4.2206-2213.

[48] V. Kasinathan, A. Mustapha, T. S. Tong, M. F. C. A. Rani, and N. A. A. Rahman, "Heartbeats: Music recommendation system with fuzzy inference engine," Indones. J. Electr. Eng. Comput. Sci., vol. 16, no. 1, pp. 275-282, 2019, doi: 10.11591/ijeecs.v16.i1.pp275-282.

[49] F. Hashim, R. Mohamad, M. Kassim, S. I. Suliman, N. M. Anas, and A. Z. A. Bakar, "Implementation of embedded real-time monitoring temperature and humidity system," Indones. J. Electr. Eng. Comput. Sci., vol. 16, no. 1, pp. 184-190, 2019, doi: 10.11591/ijeecs.v16.i1.pp184-190.

[50] S. N. Syed Nasir, J. J. Jamian, and M. W. Mustafa, "Minimizing harmonic distortion impact cause by cs using meta heuristic technique," Telkomnika (Telecommunication Comput. Electron. Control., vol. 17, no. 4, pp. 1992-2000, 2019, doi: 10.12928/TELKOMNIKA.v17i4.12768.

[51] F. S. M. Alkhafaji, W. Z. Wan Hasan, M. M. Isa, and N. Sulaiman, "A response time reduction for DC motor controller using SISO technique,” Indones. J. Electr. Eng. Comput. Sci., vol. 17, no. 2, pp. 895-906, 2019, doi: 10.11591/ijeecs.v17.i2.pp895-906.

[52] S. M. Khatami, M. Maadi, and R. Ramezani, "A clustering expert system using particle swarm optimization and k-means++ for journal recommendation to publish the papers," Indones. J. Electr. Eng. Comput. Sci., vol. 12, no. 2, pp. 814-823, 2018, doi: 10.11591/ijeecs.v12.i2.pp814-823.

[53] V.-D. Bui, T.-T. Nguyen, N.-H. Than, and D.-M. Nguyen, "A suitable structure to control the system of quad-rotor miniature aerial vehicles," Int. J. Power Electron. Drive Syst., vol. 9, no. 4, pp. 1634-1643, 2018, doi: 10.11591/ijpeds.v9n4.pp1634-1643.

[54] H. S. Hamad and A. H. Ali, "An adaptable different-levels cascaded H-bridge inverter analysis for PV grid-connected systems," Int. J. Power Electron. Drive Syst., vol. 9, no. 4, pp. 1755-1764, 2018, doi: 10.11591/ijpeds.v9n4.pp1755-1764.

[55] H. K. Omar, K. H. Jihad, and S. F. Hussein, "Comparative analysis of the essential cpu scheduling algorithms," Bull. Electr. Eng. Informatics, vol. 10, no. 5, pp. 2742-2750, 2021, doi: 10.11591/eei.v10i5.2812.

[56] Q.-V. Ngo and T.-T. Nguyen, "The mppt algorithm combined with pitch angle control for the small-scale wind turbine in a wide speed range," Int. J. Power Electron. Drive Syst., vol. 12, no. 3, pp. 1482-1493, 2021, doi: 10.11591/ijpeds.v12.i3.pp1482-1493.

[57] A. H. M. Almawgani et al., "Smart and efficient system for the detection of wrong cars parking," Bull. Electr. Eng. Informatics, vol. 10, no. 4, pp. 1968-1978, 2021, doi: 10.11591/EEI.V10I4.2634.

[58] Y. Baba and M. Bouzi, "A study on modeling of a piezoelectric motor," Int. J. Power Electron. Drive Syst., vol. 12, no. 2, pp. 695-702, 2021, doi: 10.11591/ijpeds.v12.i2.pp695-702.

[59] M. Moutchou, A. Jbari, and Y. Abouelmahjoub, "Implementation of reduced induction machine fuzzy logic control, based on dspace-1104 r\&d controller board," Int. J. Power Electron. Drive Syst., vol. 12, no. 2, pp. 1015-1023, 2021, doi: 10.11591/ijpeds.v12.i2.pp1015-1023.

[60] Z. Mekrini, S. Bri, J. Bouchnaif, and B. Bossoufi, "Experimental results of vector control for an asynchronous machine," Telkomnika (Telecommunication Comput. Electron. Control., vol. 18, no. 6, pp. 3285-3292, 2020, doi: 10.12928/TELKOMNIKA.v18i6.12707.

[61] A. A. Firdaus, R. T. Yunardi, E. I. Agustin, T. E. Putri, and D. O. Anggriawan, "Short-term photovoltaics power forecasting using Jordan recurrent neural network in Surabaya," Telkomnika (Telecommunication Comput. Electron. Control., vol. 18, no. 2, pp. 1089-1094, 2020, doi: 10.12928/TELKOMNIKA.v18i2.14816.

[62] N. S. Nordin, M. Ismail, and N. Omar, "Fuzzy modelling using butterfly optimization algorithm for phishing detection," Int. $J$. Adv. Trends Comput. Sci. Eng., vol. 9, no. 1 Special Issue 5, pp. 355-360, Oct. 2020, doi: 10.30534/ijatcse/2020/5091.52020.

[63] S. Berhil, H. Benlahmar, and N. Labani, "A review paper on artificial intelligence at the service of human resources

Int J Artif Intell, Vol. 11, No. 1, March 2022: 50-64 
management," Indones. J. Electr. Eng. Comput. Sci., vol. 18, no. 1, pp. 32-40, 2019, doi: 10.11591/ijeecs.v18.i1.pp32-40.

[64] A. H. Miry and G. A. Aramice, "Water monitoring and analytic based ThingSpeak," Int. J. Electr. Comput. Eng., vol. 10, no. 4, pp. 3588-3595, 2020, doi: 10.11591/ijece.v10i4.pp3588-3595.

[65] D. Kucherov, A. Kozub, O. Sushchenko, and R. Skrynkovskyy, "Stabilizing the spatial position of a quadrotor by the backstepping procedure," Indones. J. Electr. Eng. Comput. Sci., vol. 23, no. 2, pp. 1188-1199, 2021, doi: 10.11591/ijeecs.v23.i2.pp1188-1199.

[66] M. Díaz-Choque et al., "Automated system for monitoring and control of the liquid wax production process," Indones. J. Electr. Eng. Comput. Sci., vol. 23, no. 2, pp. 782-790, 2021, doi: 10.11591/ijeecs.v23.i2.pp782-790.

[67] M. Abdel-Basset, L. Abdel-Fatah, and A. K. Sangaiah, "Chapter 10 - Metaheuristic Algorithms: A Comprehensive Review," in Computational Intelligence for Multimedia Big Data on the Cloud with Engineering Applications, A. K. Sangaiah, M. Sheng, and Z. Zhang, Eds. Academic Press, 2018, pp. 185-231.

[68] M. Shehab, A. T. Khader, and M. A. Al-Betar, "A survey on applications and variants of the cuckoo search algorithm," Appl. Soft Comput., 2017, doi: 10.1016/j.asoc.2017.02.034.

[69] I. Boussaïd, J. Lepagnot, and P. Siarry, “A survey on optimization metaheuristics,” Inf. Sci. (Ny)., vol. 237, pp. 82-117, 2013.

[70] J. B. Odili, "The dawn of metaheuristic algorithms," Int. J. Softw. Eng. Comput. Syst., vol. 4, no. 2, pp. 49-61, 2018.

[71] S. Binitha and S. S. Sathya, "A Survey of Bio inspired Optimization Algorithms," Int. J. Soft Comput. Eng., vol. 2, no. 2, pp. 137151,2012

[72] S. Kadry, V. Rajinikanth, J. Koo, and B.-G. Kang, "Image multi-level-thresholding with Mayfly optimization," Int. J. Electr. Comput. Eng., vol. 11, no. 6, pp. 5420-5429, 2021, doi: 10.11591/ijece.v11i6.pp5420-5429.

[73] T. P. Van, V. Snášel, and T. T. Nguyen, "Antlion optimization algorithm for optimal non-smooth economic load dispatch," Int. J. Electr. Comput. Eng., vol. 10, no. 2, pp. 1187-1199, 2020, doi: 10.11591/ijece.v10i2.pp1187-1199.

[74] M. Al-Shabi, C. Ghenai, M. Bettayeb, F. F. Ahmad, and M. E. H. Assad, "Estimating pv models using multi-group salp swarm algorithm," IAES Int. J. Artif. Intell., vol. 10, no. 2, pp. 398-406, 2021, doi: 10.11591/IJAI.V10.I2.PP398-406.

[75] A. V Vitianingsih, N. Suryana, and Z. Othman, "Spatial analysis model for traffic accident-prone roads classification: A proposed framework," IAES Int. J. Artif. Intell., vol. 10, no. 2, pp. 365-373, 2021, doi: 10.11591/ijai.v10.i2.pp365-373.

[76] S. S. Mohamed Ali, A. H. Alsaeedi, D. Al-Shammary, H. H. Alsaeedi, and H. W. Abid, "Efficient intelligent system for diagnosis pneumonia (SARSCOVID19) in X-ray images empowered with initial clustering," Indones. J. Electr. Eng. Comput. Sci., vol. 22, no. 1, pp. 241-251, 2021, doi: 10.11591/ijeecs.v22.i1.pp241-251.

[77] R. Storn and K. Price, "Differential Evolution - A Simple and Efficient Heuristic for global Optimization over Continuous Spaces," J. Glob. Optim., vol. 11, no. 4, pp. 341-359, 1997.

[78] S.Poongothai et al., "Application of Fuzzy Differential Evolutionary Algorithms in Biological Data Mining," Int. J. Sci. Eng. Res., vol. 10, no. 1, pp. 1379-1382, 2019, [Online]. Available: http://www.ijser.org.

[79] S. R. Salkuti, "Short-term optimal hydro-thermal scheduling using clustered adaptive teaching learning based optimization," Int. J. Electr. Comput. Eng., vol. 9, no. 5, pp. 3359-3365, 2019, doi: 10.11591/ijece.v9i5.pp3359-3365.

[80] N. F. B. Aswan, M. N. Abdullah, and A. H. A. Bakar, "A review of combined economic emission dispatch for optimal power dispatch with renewable energy," Indones. J. Electr. Eng. Comput. Sci., vol. 16, no. 1, pp. 33-40, 2019, doi: 10.11591/ijeecs.v16.i1.pp33-40.

[81] L. H. Pham, T. T. Nguyen, L. D. Pham, and N. H. Nguyen, "Stochastic fractal search based method for economic load dispatch," Telkomnika (Telecommunication Comput. Electron. Control., vol. 17, no. 5, pp. 2535-2546, 2019, doi: 10.12928/TELKOMNIKA.v17i5.12539.

[82] K. Rajesh and N. Visali, "Hybrid method for achieving Pareto front on economic emission dispatch," Int. J. Electr. Comput. Eng., vol. 10, no. 4, pp. 3358-3366, 2020, doi: 10.11591/ijece.v10i4.pp3358-3366.

[83] A. M. Abdulazeez, D. M. Hajy, D. Q. Zeebaree, and D. A. Zebari, "Robust watermarking scheme based LWT and SVD using artificial bee colony optimization," Indones. J. Electr. Eng. Comput. Sci., vol. 21, no. 2, pp. 1218-1229, 2020, doi: 10.11591/ijeecs.v21.i2.pp1218-1229.

[84] M. Belazzoug, A. Chanane, and K. Sebaa, "An efficient NSCE algorithm for multi-objective reactive power system compensation with UPFC,” Indones. J. Electr. Eng. Comput. Sci., vol. 22, no. 2, pp. 40-51, 2020, doi: 10.11591/ijeecs.v22.i2.pp40-51.

[85] M. Iqbal, N. M. Nawi, and R. B. Mohamad, "An improved flower pollination solution for economic dispatch with valve point effect," Indones. J. Electr. Eng. Comput. Sci., vol. 22, no. 2, pp. 21-29, 2020, doi: 10.11591/ijeecs.v22.i2.pp21-29.

[86] S. K. Gachhayat and S. K. Dash, "Modified sub-gradient based combined objective technique and evolutionary programming approach for economic dispatch involving valve-point loading, enhanced prohibited zones and ramp rate constraints," Int. J. Electr. Comput. Eng., vol. 10, no. 5, pp. 5048-5057, 2020, doi: 10.11591/IJECE.V10I5.PP5048-5057.

[87] H. S. Maharana and S. K. Dash, "Dual objective multiconstraint swarm optimization based advanced economic load dispatch," Int. J. Electr. Comput. Eng., vol. 11, no. 3, pp. 1924-1932, 2021, doi: 10.11591/ijece.v11i3.pp1924-1932.

[88] B. B. Acharya, S. Dhakal, A. Bhattarai, and N. Bhattarai, "Pid speed control of dc motor using meta-heuristic algorithms," Int. J. Power Electron. Drive Syst., vol. 12, no. 2, pp. 822-831, 2021, doi: 10.11591/ijpeds.v12.i2.pp822-831.

[89] T. M. Phan, P. T. Ha, T. L. Duong, and T. T. Nguyen, "Improved particle swarm optimization algorithms for economic load dispatch considering electric market," Int. J. Electr. Comput. Eng., vol. 10, no. 4, pp. 3918-3926, 2020, doi: 10.11591/ijece.v10i4.pp3918-3926.

[90] A. H. Halim and I. Ismail, "Tree physiology optimization in constrained optimization problem," Telkomnika (Telecommunication Comput. Electron. Control., vol. 16, no. 2, pp. 876-882, 2018, doi: 10.12928/TELKOMNIKA.v16i2.9021.

[91] A. Oukennou, A. Sandali, and S. Elmoumen, "Coordinated placement and setting of FACTS in electrical network based on KalaiSmorodinsky bargaining solution and voltage deviation index," Int. J. Electr. Comput. Eng., vol. 8, no. 6, pp. 4079-4088, 2018, doi: 10.11591/ijece.v8i6.pp.4079-4088.

[92] A. Azmi, S. M. Zali, M. N. Abdullah, M. F. N. Tajuddin, and S. R. A. Rahim, "The performance of COR optimization using different constraint handling strategies to solve ELD," Indones. J. Electr. Eng. Comput. Sci., vol. 17, no. 2, pp. 680-688, 2019, doi: 10.11591/ijeecs.v17.i2.pp680-688.

[93] N. Hashim and Z. Salam, "Critical evaluation of soft computing methods for maximum power point tracking algorithms of photovoltaic systems," Int. J. Power Electron. Drive Syst., vol. 10, no. 1, pp. 548-561, 2019, doi: 10.11591/ijpeds.v10n1.pp548561 .

[94] I. Tahyudin and H. Nambo, "Improved optimization of numerical association rule mining using hybrid particle swarm optimization and cauchy distribution," Int. J. Electr. Comput. Eng., vol. 9, no. 2, pp. 1359-1373, 2019, doi: 10.11591/ijece.v9i2.pp1359-1373.

[95] S. C. B. Semlali, M. E. Riffi, and F. Chebihi, "Parallel hybrid chicken swarm optimization for solving the quadratic assignment problem," Int. J. Electr. Comput. Eng., vol. 9, no. 3, pp. 2064-2074, 2019, doi: 10.11591/ijece.v9i3.pp2064-2074. 
[96] S. A. Yasear and K. R. Ku-Mahamud, "Non-dominated sorting Harris's hawk multi-objective optimizer based on reference point approach," Indones. J. Electr. Eng. Comput. Sci., vol. 15, no. 3, pp. 1603-1614, 2019, doi: 10.11591/ijeecs.v15.i3.pp1603-1614.

[97] K. Devika and G. Jeyakumar, "Theoretical analysis and empirical comparison of different population initialization techniques for evolutionary algorithms," Indones. J. Electr. Eng. Comput. Sci., vol. 12, no. 1, pp. 87-94, 2018, doi: 10.11591/ijeecs.v12.i1.pp8794.

[98] K. Cabana, J. Candelo, R. Castillo, and E. De-La-Hoz-Franco, "Voltage sensitivity analysis to determine the optimal integration of distributed generation in distribution systems," Int. J. Electr. Comput. Eng., vol. 9, no. 1, pp. 55-65, 2019, doi: 10.11591/ijece.v9i1.pp55-65.

[99] X. Tan and S.-Y. Shin, "Differential evolution algorithm of soft island model based on K-means clustering," Indones. J. Electr. Eng. Comput. Sci., vol. 19, no. 3, pp. 1548-1555, 2020, doi: 10.11591/ijeecs.v19.i3.pp1548-1555.

[100] A. Faris, I. Musirin, S. Jelani, S. A. Ismail, M. H. Mansor, and A. V Senthil Kumar, "Tap changer optimisation using embedded differential evolutionary programming technique for loss control in power system," Bull. Electr. Eng. Informatics, vol. 9, no. 6, pp. 2253-2260, 2020, doi: 10.11591/eei.v9i6.2505.

[101] J. R. Sampson, “Adaptation in natural and artificial systems (John H. Holland).” Society for Industrial and Applied Mathematics, 1976.

[102] A. A. K. Taher and S. M. Kadhim, "Improvement of genetic algorithm using artificial bee colony," Bull. Electr. Eng. Informatics, vol. 9, no. 5, pp. 2125-2133, 2020, doi: 10.11591/eei.v9i5.2233.

[103] Z. H. Ali, A. K. Hussein, H. K. Abass, and E. Fadel, "Extractive multi document summarization using harmony search algorithm," Telkomnika (Telecommunication Comput. Electron. Control., vol. 19, no. 1, pp. 89-95, 2021, doi: 10.12928/TELKOMNIKA.V19I1.15766.

[104] M. L. Mfenjou, A. A. A. Ari, A. N. Njoya, Kolyang, W. Abdou, and A. M. Gueroui, "A multi-objective evolutionary scheme for control points deployment in intelligent transportation systems," Int. J. Electr. Comput. Eng., vol. 11, no. 2, pp. 1641-1655, 2021, doi: 10.11591/ijece.v11i2.pp1641-1655.

[105] M. Chattoraj and U. R. Vinayakamurthy, "A self adaptive new crossover operator to improve the efficiency of the genetic algorithm to find the shortest path," Indones. J. Electr. Eng. Comput. Sci., vol. 23, no. 2, pp. 1011-1017, 2021, doi: 10.11591/ijeecs.v23.i2.pp1011-1017

[106] S. S. Sadiq, A. M. Abdulazeez, and H. Haron, "Solving multi-objective master production schedule problem using memetic algorithm," Indones. J. Electr. Eng. Comput. Sci., vol. 18, no. 2, pp. 938-945, 2020, doi: 10.11591/ijeecs.v18.i2.pp938-945.

[107] Umar, Firdaus, A. Soeprijanto, and O. Penangsang, "Optimal expenditure and benefit cost based location, size and type of DGs in microgrids systems using adaptive real coded genetic algorithm," Telkomnika (Telecommunication Comput. Electron. Control., vol. 16, no. 1, pp. 10-17, 2018, doi: 10.12928/telkomnika.v16i1.6761.

[108] M. Yusoff and A. A. Othman, "Genetic algorithm with elitist-tournament for clashes-free slots of lecturer timetabling problem," Indones. J. Electr. Eng. Comput. Sci., vol. 12, no. 1, pp. 303-309, 2018, doi: 10.11591/ijeecs.v12.i1.pp303-309.

[109] K. Kamil, K. H. Chong, H. Hashim, and S. A. Shaaya, “A multiple mitosis genetic algorithm," IAES Int. J. Artif. Intell., vol. 8, no. 3, pp. 252-258, 2019, doi: 10.11591/ijai.v8.i3.pp252-258

[110] M. W. B. Peeyee, S. Abdul-Rahman, N. H. A. Hamid, and M. Zakaria, "Heuristic based model for groceries shopping navigator," Indones. J. Electr. Eng. Comput. Sci., vol. 16, no. 2, pp. 932-940, 2019, doi: 10.11591/ijeecs.v16.i2.pp932-940.

[111] D. L. Shanthi and K. Prasanna, "Energy efficient intelligent routing in WSN using dominant genetic algorithm," Int. J. Electr. Comput. Eng., vol. 10, no. 1, pp. 500-511, 2020, doi: 10.11591/ijece.v10i1.pp500-511.

[112] Z. A. Ali, S. A. Rasheed, and N. No'man Ali, "An enhanced hybrid genetic algorithm for solving traveling salesman problem," Indones. J. Electr. Eng. Comput. Sci., vol. 18, no. 2, pp. 1035-1039, 2020, doi: 10.11591/ijeecs.v18.i2.pp1035-1039.

[113] S. Masrom, M. Mohamad, S. M. Hatim, N. Baharun, N. Omar, and A. S. Abd. Rahman, "Different mutation and crossover set of genetic programming in an automated machine learning," IAES Int. J. Artif. Intell., vol. 9, no. 3, pp. 402-408, 2020, doi: 10.11591/ijai.v9.i3.pp402-408

[114] I. M. Khudher and Y. I. Ibrahim, "Swarm intelligent hyperdization biometric," Indones. J. Electr. Eng. Comput. Sci., vol. 18, no. 1, pp. 385-395, 2019, doi: 10.11591/ijeecs.v18.i1.pp385-395.

[115] K. Loubna, B. Bachir, and Z. Izeddine, "Ant colony optimization for optimal low-pass state variable filter sizing," Int. J. Electr. Comput. Eng., vol. 8, no. 1, pp. 227-235, 2018, doi: 10.11591/ijece.v8i1.pp227-235.

[116] D. Tian, "EFPSO: An Effective Fuzzy Particle Swarm Optimization and Its Applications," 2018.

[117] M. Tuberquia and C. Hernandez, "New approaches in cognitive radios using evolutionary algorithms," Int. J. Electr. Comput. Eng., vol. 8, no. 3, pp. 1636-1646, 2018, doi: 10.11591/ijece.v8i3.pp1636-1646.

[118] M. Sankaraiah, S. Suresh Reddy, and M. Vijaya Kumar, "GWO based optimal reactive power coordination of DFIG, ULTC and capacitors," Indones. J. Electr. Eng. Comput. Sci., vol. 11, no. 3, pp. 805-813, 2018, doi: 10.11591/ijeecs.v11.i3.pp805-813.

[119] M. A. A. Rahman, B. Ismail, K. Naidu, and M. K. Rahmat, "Review on population-based metaheuristic search techniques for optimal power flow,” Indones. J. Electr. Eng. Comput. Sci., vol. 15, no. 1, pp. 373-381, 2019, doi: 10.11591/ijeecs.v15.i1.pp373381 .

[120] S. Ibrahim, N. E. A. Khalid, and M. Manaf, "CAPSOCA: Hybrid technique for nosologic segmentation of primary brain tumors," Indones. J. Electr. Eng. Comput. Sci., vol. 16, no. 1, pp. 267-274, 2019, doi: 10.11591/ijeecs.v16.i1.pp267-274.

[121] S. R. Salkuti, "Optimal location and sizing of DG and D-STATCOM in distribution networks," Indones. J. Electr. Eng. Comput. Sci., vol. 16, no. 3, pp. 1107-1114, 2019, doi: 10.11591/ijeecs.v16.i3.pp1107-1114

[122] A. S. Alkhafaji, A. A. Al-Hayder, and A. S. Hassooni, "Hybrid IWOPSO optimization based marine engine rotational speed control automatic system," Int. J. Electr. Comput. Eng., vol. 10, no. 1, pp. 840-848, 2020, doi: 10.11591/ijece.v10i1.pp840-848.

[123] M. Yusoff, A. N. M. Basir, N. A. Kadir, and S. A. Bahari, "Evaluation of particle swarm optimization for strength determination of tropical wood polymer composite," IAES Int. J. Artif. Intell., vol. 9, no. 2, pp. 364-370, 2020, doi: 10.11591/ijai.v9.i2.pp364370.

[124] J. Kennedy and R. Eberhart, "Particle swarm optimization," in Proceedings of ICNN'95-international conference on neural networks, 1995, vol. 4, pp. 1942-1948.

[125] D. Li, Q. He, L. Chunli, and Y. Hongjie, "Local binary fitting segmentation by cooperative quantum particle optimization," Telkomnika (Telecommunication Comput. Electron. Control., vol. 15, no. 1, pp. 531-539, 2017, doi: 10.12928/TELKOMNIKA.v15i1.3159.

[126] O. P. Verma and N. Sharma, "Intensity preserving cast removal in color images using particle swarm optimization," Int. J. Electr. Comput. Eng., vol. 7, no. 5, pp. 2581-2595, 2017, doi: 10.11591/ijece.v7i5.pp2581-2595.

[127] N. A. Md Ghani, S. B. A. Kamaruddin, N. M. Ramli, I. Musirin, and H. Hashim, "Modified BPNN via iterated least median squares, particle Swarm optimization and firefly algorithm," Indones. J. Electr. Eng. Comput. Sci., vol. 8, no. 3, pp. 779-786,

Int J Artif Intell, Vol. 11, No. 1, March 2022: 50-64 
2017, doi: 10.11591/ijeecs.v8.i3.pp779-786.

[128] P. Hemavathi and A. N. Nandakumar, "Novel scheme for minimal iterative PSO algorithm for extending network lifetime of wireless sensor network," Int. J. Electr. Comput. Eng., vol. 8, no. 2, pp. 1084-1091, 2018, doi: 10.11591/ijece.v8i2.pp1084-1091.

[129] M. R. M. Sapiee and K. A. M. Annuar, "Synchronous mobile Robots formation control," Telkomnika (Telecommunication Comput. Electron. Control., vol. 16, no. 3, pp. 1183-1192, 2018, doi: 10.12928/TELKOMNIKA.v16i3.8397.

[130] Z. Frijet, A. Zribi, and M. Chtourou, "An adaptive neural network controller based on PSO and gradient descent method for PMSM speed drive," Int. J. Power Electron. Drive Syst., vol. 9, no. 3, pp. 1412-1422, 2018, doi: 10.11591/ijpeds.v9n3.pp14121422.

[131] M. Takruri, M. K. A. Mahmoud, and A. Al-Jumaily, "PSO-SVM hybrid system for melanoma detection from histo-pathological images," Int. J. Electr. Comput. Eng., vol. 9, no. 4, pp. 2941-2949, 2019, doi: 10.11591/ijece.v9i4.pp2941-2949.

[132] G. Jayagopi and S. Pushpa, "On the classification of arrhythmia using supplementary features from tetrolet transforms," Int. J. Electr. Comput. Eng., vol. 9, no. 6, pp. 5006-5015, 2019, doi: 10.11591/ijece.v9i6.pp5006-5015.

[133] H. Bouyghf, B. Benhala, and A. Raihani, "Analysis of the impact of metal thickness and geometric parameters on the quality factor-Q in integrated spiral inductors by means of artificial bee colony technique," Int. J. Electr. Comput. Eng., vol. 9, no. 4, pp. 2918-2931, 2019, doi: 10.11591/ijece.v9i4.pp2918-2931.

[134] O. V Lee et al., "A malicious URLs detection system using optimization and machine learning classifiers," Indones. J. Electr. Eng. Comput. Sci., vol. 17, no. 3, pp. 1210-1214, 2019, doi: 10.11591/ijeecs.v17.i3.pp1210-1214.

[135] A. Mishra and S. Dehuri, "Real-time online fingerprint image classification using adaptive hybrid techniques," Int. J. Electr. Comput. Eng., vol. 9, no. 5, pp. 4372-4381, 2019, doi: 10.11591/ijece.v9i5.

[136] Y. Hendrawan, S. Widyaningtyas, and S. Sucipto, "Computer vision for purity, phenol, and pH detection of Luwak coffee green bean," Telkomnika (Telecommunication Comput. Electron. Control., vol. 17, no. 6, pp. 3073-3085, 2019, doi: 10.12928/TELKOMNIKA.v17i6.12689.

[137] V. Jaiswal, V. Sharma, and S. Varma, "MMFO: Modified moth flame optimization algorithm for region based RGB color image segmentation," Int. J. Electr. Comput. Eng., vol. 10, no. 1, pp. 196-204, 2020, doi: 10.11591/ijece.v10i1.pp196-204.

[138] I. K. Mohammed and A. I. Abdulla, "Elevation, pitch and travel axis stabilization of 3DOF helicopter with hybrid control system by GA-LQR based PID controller," Int. J. Electr. Comput. Eng., vol. 10, no. 2, pp. 1868-1884, 2020, doi: 10.11591/ijece.v10i2.pp1868-1884.

[139] M. Z. M. Tumari, A. F. Z. Abidin, A. S. R. A. Subki, A. W. A. Aziz, M. S. Saealal, and M. A. Ahmad, "Liquid slosh control by implementing model-free PID controller with derivative filter based on PSO," Indones. J. Electr. Eng. Comput. Sci., vol. 18, no. 2, pp. 750-758, 2020, doi: 10.11591/ijeecs.v18.i2.pp750-758.

[140] M. J. Fadhil, M. N. Hawas, and M. A. Naji, "Architecture neural network deep optimizing based on self organizing feature map algorithm," Bull. Electr. Eng. Informatics, vol. 9, no. 6, pp. 2538-2546, 2020, doi: 10.11591/eei.v9i6.1935.

[141] B. Madhu and G. Holi, "An optimal and secure watermarking system using SWT-SVD and PSO," Indones. J. Electr. Eng. Comput. Sci., vol. 18, no. 2, pp. 917-926, 2020, doi: 10.11591/IJEECS.V18.I2.PP917-926.

[142] M. S. Amiri, M. F. Ibrahim, and R. Ramli, "Optimal parameter estimation for a DC motor using genetic algorithm," Int. J. Power Electron. Drive Syst., vol. 11, no. 2, pp. 1047-1054, 2020, doi: 10.11591/ijpeds.v11.i2.pp1047-1054.

[143] V. Sivasankarareddy and G. Sundari, "Survey on wireless sensor networks: Energy efficient optimization routing algorithms," Indones. J. Electr. Eng. Comput. Sci., vol. 19, no. 2, pp. 756-765, 2020, doi: 10.11591/ijeecs.v19.i2.pp756-765.

[144] N. H. Abbas, "Tuning of different controlling techniques for magnetic suspending system using an improved bat algorithm," Int. J. Electr. Comput. Eng., vol. 10, no. 3, pp. 2402-2415, 2020, doi: 10.11591/ijece.v10i3.pp2402-2415.

[145] S. B. Sabikan, S. W. Nawawi, and N. A. A. Aziz, "Modelling of time-to collision for unmanned aerial vehicle using particles swarm optimization," IAES Int. J. Artif. Intell., vol. 9, no. 3, pp. 488-496, 2020, doi: 10.11591/ijai.v9.i3.pp488-496.

[146] H. Nurhadi, E. Apriliani, T. Herlambang, and D. Adzkiya, "Sliding mode control design for autonomous surface vehicle motion under the influence of environmental factor," Int. J. Electr. Comput. Eng., vol. 10, no. 5, pp. 4789-4797, 2020, doi: 10.11591/ijece.v10i5.pp4789-4797.

[147] A. M. Hasan and S. M. Rafaat, "Optimized formation control of multi-agent system using PSO algorithm," Indones. J. Electr. Eng. Comput. Sci., vol. 20, no. 3, pp. 1591-1600, 2020, doi: 10.11591/ijeecs.v20.i3.pp1591-1600.

[148] M. R. M. Romlay, S. F. Toha, A. M. Ibrahim, and I. Venkat, "Methodologies and evaluation of electronic travel aids for the visually impaired people: A review," Bull. Electr. Eng. Informatics, vol. 10, no. 3, pp. 1747-1758, 2021, doi: 10.11591/eei.v10i3.3055.

[149] K. S. Gaeid, A. F. Nashee, I. A. Ahmed, and M. H. Dekheel, "Robot control and kinematic analysis with 6DoF manipulator using direct kinematic method," Bull. Electr. Eng. Informatics, vol. 10, no. 1, pp. 70-78, 2021, doi: 10.11591/eei.v10i1.2482.

[150] X.-K. Dang, H.-N. Truong, V.-C. Nguyen, and T.-D.-A. Pham, "Applying convolutional neural networks for limited-memory application," Telkomnika (Telecommunication Comput. Electron. Control., vol. 19, no. 1, pp. 244-251, 2021, doi: 10.12928/TELKOMNIKA.V19I1.16232

[151] A. F. Algamluoli and N. H. Abbas, "Speed controller design for three-phase induction motor based on dynamic adjustment grasshopper optimization algorithm," Int. J. Electr. Comput. Eng., vol. 11, no. 2, pp. 1143-1157, 2021, doi: 10.11591/ijece.v11i2.pp1143-1157.

[152] M. Yanto, S. Sanjaya, Yulasmi, D. Guswandi, and S. Arlis, "Implementation multiple linear regresion in neural network predict gold price," Indones. J. Electr. Eng. Comput. Sci., vol. 22, no. 3, pp. 1635-1642, 2021, doi: 10.11591/ijeecs.v22.i3.pp1635-1642.

[153] J. A. Jupin, T. Sutikno, M. A. Ismail, M. S. Mohamad, and S. Kasim, "Review of the machine learning methods in the classification of phishing attack," Bull. Electr. Eng. Informatics, vol. 8, no. 4, 2019, doi: 10.11591/eei.v8i4.1922.

[154] W. A. Jbara, "Ear biometric verification approach based on morphological and geometric invariants," Indones. J. Electr. Eng. Comput. Sci., vol. 20, no. 3, pp. 1479-1484, 2020, doi: 10.11591/ijeecs.v20.i3.pp1479-1484.

[155] V. Jaiswal, V. Sharma, and S. Varma, "An implementation of novel genetic based clustering algorithm for color image segmentation," Telkomnika (Telecommunication Comput. Electron. Control., vol. 17, no. 3, pp. 1461-1467, 2019, doi: 10.12928/TELKOMNIKA.v17i3.10072.

[156] Z. Feng and B. Zhang, "Fuzzy clustering image segmentation based on particle swarm optimization," Telkomnika (Telecommunication Comput. Electron. Control., vol. 13, no. 1, pp. 128-136, 2015, doi: 10.12928/TELKOMNIKA.v13i1.1269.

[157] S. Bhargava and A. Somkuwar, "Evaluation of noise exclusion of medical images using hybridization of partical swarm optimization and bivariate shrinkage methods," Int. J. Electr. Comput. Eng., vol. 5, no. 3, pp. 421-428, 2015, doi: 10.11591/ijece.v5i3.pp421-428.

[158] D. K. Sambariya and S. Shrangi, "Optimal design of PID controller for load frequency control using harmony search algorithm," Indones. J. Electr. Eng. Comput. Sci., vol. 5, no. 1, pp. 19-32, 2017, doi: 10.11591/ijeecs.v5.i1.pp19-32.

[159] M. Rofiq et al., "Integrating fuzzy logic and genetic algorithm for upwelling prediction in Maninjau Lake," Telkomnika 
(Telecommunication Comput. Electron. Control., vol. 17, no. 1, pp. 226-234, 2019, doi: 10.12928/TELKOMNIKA.v17i1.11605.

[160] Y. K. Qawqzeh et al., "Applying the big bang-big crunch metaheuristic to large-sized operational problems," Int. J. Electr. Comput. Eng., vol. 10, no. 3, pp. 2484-2502, 2020, doi: 10.11591/ijece.v10i3.pp2484-2502.

[161] O. M. Neda, "A new hybrid algorithm for solving distribution network reconfiguration under different load conditions," Indones. J. Electr. Eng. Comput. Sci., vol. 20, no. 3, pp. 1118-1127, 2020, doi: 10.11591/ijeecs.v20.i3.pp1118-1127.

[162] R. V Rao, V. J. Savsani, and D. P. Vakharia, "Teaching-Learning-Based Optimization: An optimization method for continuous non-linear large scale problems," Inf. Sci. (Ny)., vol. 183, no. 1, pp. 1-15, Jan. 2012, doi: 10.1016/j.ins.2011.08.006.

[163] H. R. Ibraheem, Z. F. Hussain, S. M. Ali, M. Aljanabi, M. A. Mohammed, and T. Sutikno, "A new model for large dataset dimensionality reduction based on TLBO and LR," Telkomnika (Telecommunication Comput. Electron. Control., vol. 18, no. 3, pp. 1688-1694, 2020, doi: 10.12928/TELKOMNIKA.v18i3.13764.

[164] S. K. A. Attari, M. Bakhshipour, M. Shakarami, and F. Namdari, "A novel method based on teaching-learning-based optimization for recloser placement with load model consideration in distribution system," Indones. J. Electr. Eng. Comput. Sci., vol. 2, no. 1, pp. 1-10, 2016, doi: 10.11591/ijeecs.v2.i1.pp1-10.

[165] D. S. N. M. Rao and N. Kumar, "Comparisional investigation of load dispatch solutions with TLBO," Int. J. Electr. Comput. Eng., vol. 7, no. 6, pp. 3246-3253, 2017, doi: 10.11591/ijece.v7i6.pp3246-3253.

[166] P. Chaudhury and H. K. Tripathy, "Optimising the parameters of a RBFN network for a teaching learning paradigm," Indones. J. Electr. Eng. Comput. Sci., vol. 15, no. 1, pp. 435-442, 2019, doi: 10.11591/ijeecs.v15.i1.pp435-442.

[167] S. R. Salkuti, "Solving optimal generation scheduling problem of Microgrid using teaching learning based optimization algorithm," Indones. J. Electr. Eng. Comput. Sci., vol. 17, no. 3, pp. 1632-1638, 2020, doi: 10.11591/ijeecs.v17.i3.pp1632-1638.

[168] M. Khorashadizade, M. Jouyban, and M. A. Oskoei, "A hybrid constructive algorithm incorporating teaching-learning based optimization for neural network training," Int. J. Electr. Comput. Eng., vol. 10, no. 4, pp. 3725-3733, 2020, doi: 10.11591/ijece.v10i4.pp3725-3733.

[169] S. R. Salkuti, "Power system state estimation using teaching learning-based optimization algorithm," Telkomnika (Telecommunication Comput. Electron. Control., vol. 18, no. 4, pp. 2125-2131, 2020, doi: 10.12928/TELKOMNIKA.v18i4.14159.

[170] M. Jouyban and M. Khorashadizade, "Using the modified k-mean algorithm with an improved teaching-learning-based optimization algorithm for feedforward neural network training," Int. J. Electr. Comput. Eng., vol. 11, no. 6, pp. 5277-5285, 2021, doi: 10.11591/ijece.v11i6.pp5277-5285.

[171] X. X. Ma and J. S. Wang, "Optimized Parameter Settings of Binary Bat Algorithm for Solving Function Optimization Problems," J. Electr. Comput. Eng., vol. 2018, 2018, doi: 10.1155/2018/3847951.

[172] S. R. Borra, G. J. Reddy, and E. S. Reddy, "An efficient fingerprint identification using neural network and BAT algorithm," Int. J. Electr. Comput. Eng., vol. 8, no. 2, pp. 1194-1213, 2018, doi: 10.11591/ijece.v8i2.pp1194-1213.

[173] Z. Boulouard, A. El Haddadi, F. Bouhafer, A. El Haddadi, L. Koutti, and B. Dousset, "Bat-cluster: A bat algorithm-based automated graph clustering approach," Int. J. Electr. Comput. Eng., vol. 8, no. 2, pp. 1122-1130, 2018, doi: 10.11591/ijece.v8i2.pp1122-1130.

[174] R. B. Mohamed, M. M. Yusof, N. Wahid, N. Murli, and M. Othman, "Bat algorithm and k-means techniques for classification performance improvement," Indones. J. Electr. Eng. Comput. Sci., vol. 15, no. 3, pp. 1411-1418, 2019, doi: 10.11591/ijeecs.v15.i3.pp1411-1418.

[175] M. A. Faraj and A. M. Abbood, "Fractional order PID controller tuned by bat algorithm for robot trajectory control," Indones. J. Electr. Eng. Comput. Sci., vol. 21, no. 1, pp. 74-83, 2021, doi: 10.11591/ijeecs.v21.i1.pp74-83.

[176] A. N. Younis and F. M. Ramo, “A new parallel bat algorithm for musical note recognition,” Int. J. Electr. Comput. Eng., vol. 11, no. 1, pp. 558-566, 2021, doi: 10.11591/ijece.v11i1.pp558-566.

[177] H. Setiadi, K. O. Jones, T. A. Nugroho, M. Abdillah, H. Trilaksana, and T. Amrillah, "Design of spark ignition engine speed control using bat algorithm," Int. J. Electr. Comput. Eng., vol. 11, no. 1, pp. 794-801, 2021, doi: 10.11591/ijece.v11i1.pp794-801.

[178] K. Premkumar and B. V Manikandan, "Bat algorithm optimized fuzzy PD based speed controller for brushless direct current motor,” Eng. Sci. Technol. an Int. J., vol. 19, no. 2, pp. 818-840, Jun. 2016, doi: 10.1016/j.jestch.2015.11.004.

[179] M. R. M. Ridzuan, E. E. Hassan, A. R. Abdullah, and A. F. A. Kadir, "Sustainable environmental economic dispatch optimization with hybrid metaheuristic modification," Indones. J. Electr. Eng. Comput. Sci., vol. 11, no. 1, pp. 161-168, 2018, doi: 10.11591/ijeecs.v11.i1.pp161-168.

[180] L. B. Amar and W. M. Jasim, "Hybrid metaheuristic approach for robot path planning in dynamic environment," Bull. Electr. Eng. Informatics, vol. 10, no. 4, pp. 2152-2162, 2021, doi: 10.11591/EEI.V10I4.2836.

[181] A. H. Alsaeedi, A. H. Aljanabi, M. E. Manna, and A. L. Albukhnefis, "A proactive metaheuristic model for optimizing weights of artificial neural network," Indones. J. Electr. Eng. Comput. Sci., vol. 20, no. 2, pp. 976-984, 2020, doi: 10.11591/ijeecs.v20.i2.pp976-984.

[182] L. A. Bewoor, V. C. Prakash, and S. U. Sapkal, "Comparative analysis of metaheuristic approaches for makespan minimization for no wait flow shop scheduling problem," Int. J. Electr. Comput. Eng., vol. 7, no. 1, pp. 417-423, 2017, doi: 10.11591/ijece.v7i1.pp417-423.

[183] T. L. Duong, L. H. Pham, T. T. Nguyen, and T. T. Nguyen, "Application of a new constraint handling method for economic dispatch considering electric market," Bulletin of Electrical Engineering and Informatics, vol. 9, no. 4. pp. 1542-1549, 2020, doi: 10.11591/eei.v9i4.2351.

[184] T. L. Duong, L. H. Pham, T. T. Nguyen, and T. T. Nguyen, "Application of a new constraint handling method for economic dispatch considering electric market," Bulletin of Electrical Engineering and Informatics, vol. 9, no. 4. pp. 1542-1549, Aug. 2020, doi: 10.11591/eei.v9i4.2351.

[185] R. Patil, S. Tamane, S. A. Rawandale, and K. Patil, "A modified mayfly-SVM approach for early detection of type 2 diabetes mellitus," Int. J. Electr. Comput. Eng., vol. 12, no. 1, pp. 524-533, 2022, doi: 10.11591/ijece.v12i1.pp524-533.

[186] M. M. Alhato and S. Bouallègue, "Thermal exchange optimization based control of a doubly fed induction generator in wind energy conversion systems," Indones. J. Electr. Eng. Comput. Sci., vol. 20, no. 3, pp. 1252-1260, 2020, doi: 10.11591/ijeecs.v20.i3.pp1252-1260.

[187] R. Sridhar, C. S. Boopathi, D. Das, S. Agrawal, and H. Choubisa, "An ingenious invasive weed optimization (IWO) aided maximum power tracking for partially shaded photovoltaic array," Indones. J. Electr. Eng. Comput. Sci., vol. 15, no. 2, pp. 543553, 2019, doi: 10.11591/ijeecs.v15.i2.pp543-553.

[188] W. N. A.-D. Abed, O. A. Imran, and I. S. Fatah, "Automatic generation control based whale optimization algorithm," Int. J. Electr. Comput. Eng., vol. 9, no. 6, pp. 4516-4523, 2019, doi: 10.11591/ijece.v9i6.pp4516-4523.

[189] A. Taieb and A. Ferdjouni, "A new design of fuzzy logic controller optimized by PSO-SCSO applied to SFO-DTC induction

Int J Artif Intell, Vol. 11, No. 1, March 2022: 50-64 
motor drive," Int. J. Electr. Comput. Eng., vol. 10, no. 6, pp. 5813-5823, 2020, doi: 10.11591/ijece.v10i6.pp5813-5823.

[190] S. T. Suganthi, D. Devaraj, and S. H. Thilagar, "An improved differential evolution algorithm for congestion management considering voltage stability," Indian J. Sci. Technol., vol. 8, no. 24, 2015, doi: 10.17485/ijst/2015/v8i24/80243.

[191] N. Karaboga and B. Cetinkaya, "Performance comparison of genetic and differential evolution algorithms for digital FIR filter design," in International Conference on Advances in Information Systems, 2004, pp. 482-488.

[192] a. D. Lilla, M. a. Khan, and P. Barendse, "Comparison of Differential Evolution and Genetic Algorithm in the design of permanent magnet Generators,” 2013 IEEE Int. Conf. Ind. Technol., pp. 266-271, 2013, doi: 10.1109/ICIT.2013.6505683.

[193] A. García-Monzó, H. Migallón, A. Jimeno-Morenilla, J.-L. Sánchez-Romero, H. Rico, and R. V. Rao, "Efficient Subpopulation Based Parallel TLBO Optimization Algorithms," Electronics, vol. 8, no. 1, p. 19, 2019.

[194] S. Talatahari, V. Goodarzimehr, and N. Taghizadieh, "Hybrid Teaching-Learning-Based Optimization and Harmony Search for Optimum Design of Space Trusses," J. Optim. Ind. Eng., vol. 13, no. 1, pp. 177-194, 2020, doi: 10.22094/joie.2019.1866904.1649.

[195] Z. Wu and R. Xue, "A Cyclical Non-Linear Inertia-Weighted Teaching-Learning-Based Optimization Algorithm," Algorithms, vol. 12, no. 5, p. 94, May 2019, doi: 10.3390/a12050094.

\section{BIOGRAPHIES OF AUTHORS}

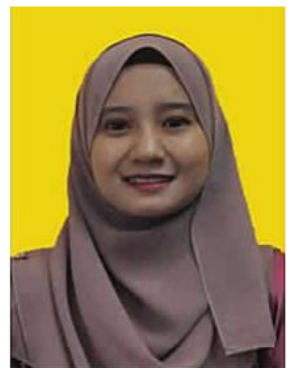

Nur Azieta Mohamad Aseri (D) $8 \mathrm{SC}$ is an admin staff of the Center Computing an Informatic, Universiti Malaysia Kelantan, Malaysia. She has experience in developing Postgraduate System for a local university by utilizing Agile Methodology using Java Spring Framework for back-end development and angular for front end development. His research interests include the field of Meta-Heuristic Algorithms, Fuzzy Modeling, Agile methodology, Java framework, and entrepreneur. Her key strengths include: working in a team, always punctual, committed with task given, innovative and creative, and can work in a stressful environment. She can be contacted at email: azieta.ma@umk.edu.my.

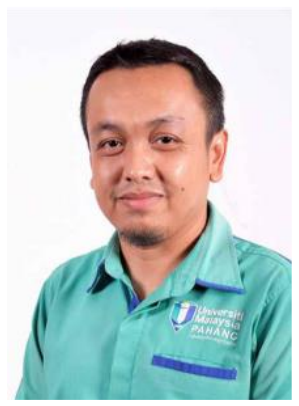

Mohd Arfian Ismail (D) 8. SC P is a Senior Lecturer at the Faculty of Computer Systems and Software Engineering in University Malaysia Pahang, Malaysia. He received B. Sc, M. Sc. and PhD degree in Computer Science from Universiti Teknologi Malaysia (UTM) in 2008, 2011 and 2016, respectively. His current research interests are in the areas of machine learning methods and optimization method. He can be contacted at email: arfian@ump.edu.my.

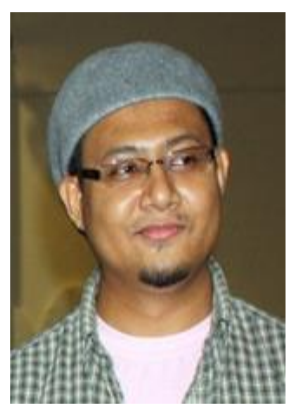

Abdul Sahli Fakharudin (D) 8D SC P is a lecturer in the Faculty of Computing, College of Computing and Applied Sciences, Universiti Malaysia Pahang. His research interest mainly in artificial neural network and machine learning and currently a member of Soft Computing and Intelligence Systems (SPINT) research group. He can be contacted at email: sahli@mp.edu.my.

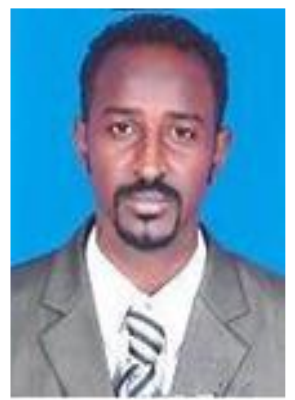

Ashraf Osman Ibrahim (D) SC P obtained BSc and MSc in Computer Science from Al Neelain University and University of Khartoum, Sudan respectively. He did his Ph.D. in Computer Science, Universiti Teknologi Malaysia (UTM), 2015. His research interest includes: computational intelligence, soft computing, artificial neural networks, evolutionary algorithms, multi-objective evolutionary algorithms, machine learning, Pattern Classification and data mining. He can be contacted at email: ashrafosman2@gmail.com. 


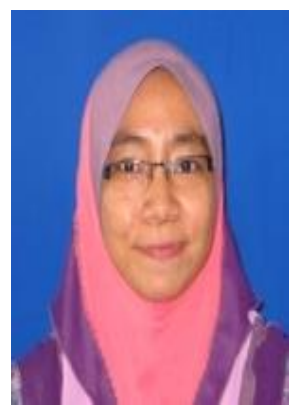

Shahreen Kasim (iD 8D SC P is currently an Associate Professor in Department of Security Information and Web Technology, Faculty of Computer Science and Information Technology, Universiti Tun Hussein Onn Malaysia. Her areas of interest include bioinformatics, soft computing, data mining, web and mobile application. She can be contacted at email: shahreen@uthm.edu.my.

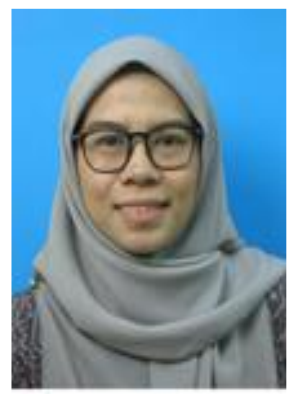

Noor Hidayah Zakaria (D) SC $\mathrm{SP}$ is a senior lecturer in the Faculty of Engineering, Universiti Teknologi Malaysia, Johor, Malaysia. Her areas of interest include neural netwok, fuzzy logic, ANFIS, soft computing, machine learning, applied artificial intelligence, social welfare and urban poverty. She can be contacted at email: noorhidayah.z@utm.my.

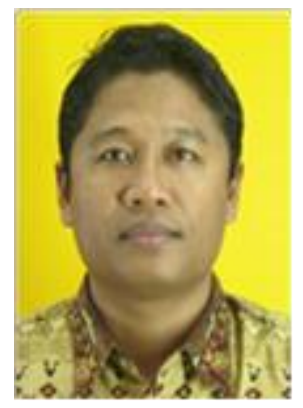

Tole Sutikno (D) 8 SC $P$ is a lecturer in Electrical Engineering Department at the Universitas Ahmad Dahlan (UAD), Yogyakarta, Indonesia. He received his B.Eng., M.Eng. and Ph.D. degrees in Electrical Engineering from Universitas Diponegoro, Universitas Gadjah Mada and Universiti Teknologi Malaysia, in 1999, 2004 and 2016, respectively. He has been an Associate Professor in UAD, Yogyakarta, Indonesia since 2008. He is currently an Editorin-Chief of the TELKOMNIKA and the Head of the Embedded Systems and Power Electronics Research Group. His research interests include the field of digital design, industrial applications, industrial electronics, industrial informatics, power electronics, motor drives, renewable energy, FPGA applications, embedded system, artificial intelligence, intelligent control, information technology and digital library. He can be contacted at email: tole@ee.uad.ac.id. 